\title{
An Account of a Mormon family's conversion to the religion of the Latter Day Saints and of their trip from Denmark to Utah*
}

\author{
Part II
}

By REV. H. N. HANSEN

\begin{abstract}
Part I of this "Account" appeared in the Summer, 197I, issue of the ANNALS.
\end{abstract}

As we progressed westward reaching the higher altitude in the mountain region the general health of the company became bitter, but by that time quite a number had fallen by the way and it had been mostly the young sturdy ones who had succumbed. Father whose health had been good while the many were sick now gave way but yet he was not so bad but what he was up and managed to walk along though it was hard on him. One night we came to camp but father was nowhere to be seen, we got our tent pitched and darkness came on yet father was not yet heard from. Of course the family became alarmed, but just as we had got camp arranged and we began to feel very uneasy he came along. $\mathrm{He}$ told us that he had become so tired and having being left behind, that he very near had given up in despair not thinking himself able to reach us.

But after resting himself a little he made another effort and finely reached camp at the late hour being guided by the campfires. Yet the next day he walked as usual, he was of that disposition that I believe he would have been left and perished in the wilderness rather than having asked for the privilege of riding.

Mother's and my health had become good towards the latter end of the journey at first just after my sickness walking was quite irksome to me, but now I felt after eating my supper at night that I was ready to start out again. We traveled on an average about twenty miles a day, which of course for a young and healthy person was easy enough to walk. But my sister's condition became no better, but rather worse so much so that she was not expected to live.

"The text of this account appears in its original form. Only the method of page designation has been changed in order to conserve space. 
I remember that friends who called around to see her would tell my parents that her suffering would soon be over. In the morning they would say, she will not live till night, and at night she will not live till morning. Yet under this condition no one was permitted to be with her in the morning. When she was carried in in the morning, and placed in the nest that was made for her in the bedding, there was no one to be with her to give her a drink or in any way to help her. But mother was in the habit of walking close by the team, and as an oxteam moves but slowly she would walk in behind the cattle at the front of the wagon and get on the wagon tongue and look under the cover to see how she was and if anything could be done for her comfort. This she had done many times and did not think there was any danger, but the last time she attempted this her dress caught on the bolt in the wagon tongue and she fell in front on the wheels and the heavy loaded wagon passed over her breast and shoulder. I was not near when the accident happened but was in the front of the company. Father had bought a cow that we might have a little milk on the road and it was my duty to drive the cow along.

I had not learned anything of what had happened until camping time. It was in the evening. I think, coming back to where our wagon had stopped I saw father by the side of it, and before I came close enough to speak I could read in his face that something was wrong. I thought my sister was dead for this was what I had been expected to learn, though we thought we had seen some change for the better in her condition the last few days. I went up to father and asked him what had happened, but he could hardly tell so overcome of grief was he. And well might he be. His two youngest children had died on the road, his only daughter lay sick and entirely helpless, lingering as it were between death and life, himself womout and sick and mother he thought was killed or would die, or if not was ruined for life. I was the only one who was well, but this was a sad blow to me at the time also. When the accident had happened of course something had to be done. 
There was not room in our wagon under the wagoncover for mother until some of the baggage was moved from that to another wagon, and a place was fixed such as could be done in a hurry by the side of my sister and mother was lifted in. Now she could ride, but in her condition it was a hard ride over rocks and boulders, as was the case in many places in this mountain region. There was no physician in our company and no one who could tell how bad she was hurt. It was hard matter to get her from the wagon to the tent at night and back again in the morning. She could not help herself and she could not stand to be lifted, but I shall not attempt to describe any farther, it can better be imagined.

I think it was about two hundred miles before reaching Salt Lake City that the accident happened to mother, and strange as it may appear by the time we reached the city she had improved so much that she with a little help could get out and in of the wagon. My sister too had improved a little, but was still entirely helpless as a little child, I remember the day when we came through the last canyon in the mountain and our eyes first beheld Salt Lake City. It was a cheerful sight, not only because of the improved condition of the country compared with the wilderness in which we had traveled for months, but it was our journeys end the land for which we had started. We needed rest and we were happy in the thought that rest was at hand. The appearance of the country did not come up to the expectation of many but most of the company did not care much for that, a rest was wanted and they were glad to make a halt anywhere for the purpose.

It was on the 5th of October that we came into Salt Lake Valley lacking only five days of six months from the day we sailed from Copenhagen Denmark. Those who now make the trip in about three weeks know nothing about the hardships of traveling in those days. Of course our trip might have been more pleasant and comfortable had those in charge had a decent respect for humanity, but we had been treated not much better than dumb brutes. We camped the first night in the valley in an enclosed field, meadow or pastureland south of Salt Lake City. I think it was on a position of 
what was known as the church farm. On the day following, our baggage was hauled up through the city into Brigham Young's yards through the eagle gate leading into his property and there our baggage was dumped off, while the merchandise on the wagons was unloaded somewhere else.

Here we were now in the capitol of Zion, the city of which we had heard so much. Many inquired about the temple of which they had sung, and to the erection of which some perhaps had donated were made was surprised to learn that only the foundation had yet been laid. One of the largest buildings which we saw, we learned was the theater. I believe then owned by Brigham Young. There were a few substantial business houses on Main Street, but the majority of the buildings were of adobies and not very elegant in appearance. A wonderful change has taken place since then, now Salt Lake City is one of the finest in the intermountain region. The railroad reached here in 1870 and wherever the ironhorse comes thrift and energy follows.

We had a friend who lived in the northern part of the Territory who had imigrated from our part of the country two years before. We expected him to meet us, but for some cause he did not turn up and we did not have a chance to get to that part of the country. We met a man by the name of Lars Larson who lived in Toelly county at a place now called Vernon. We had also come to the city, and as he informed us for the purpose of getting a family who needed a home out on his farm to work it on shares. The presenting the opportunity in glowing teens, saying he would furnish land, team and see, father to do the work and have half of the harvest. He was also to furnish a house for us to live in and employment for father and me during the winter. All this to us who came from a European Country where we never had heard of any such offer sounded good. Father did not inquire what kind a house he had on the farm, nor how much he was going to pay him a day for his work. We being a Brother in Zion, and his offers in other regard sounded liberal, it was taken for granted that we could trust him, and that he would do to us what was right. 
Several days past away before he got ready to start home, and we were waiting to go with him for father had concluded to accept his offer. He finally came one day in the forenoon and told us that he would start for home that day, and as he had a horse team. I should start immediately with the cow, he with the folks to come after and overtake me on the road. The distance from Salt Lake to his home was about seventy miles. I knew of course nothing about the road, but he pointed out to me the mountains west of the city about fifteen miles away, and told me that the road I should take would lead me round the northern point of the same into Toele Valley when I was to wait at a man's home whose name I do not now remember, until the rest came along in case they did not overtake me on the way before I got there.

I started, having a lunch along for my dinner, and had no trouble to find the road. The mountains ahead was a sure landmark, and the road I was on was the only one leading in the direction pointed out to me by Mr. Larsen. I went on with confidence, sure that I was right. I walked along leading my little spotted cow by a rope she being halterbroke and led as nicely as a horse, but the mountains did not seem to get much nearer, however I reached their base about sundown. I found water and grass and rested a while letting my cow eat some of the grass. Now for the first my situation began to look unpleasant, night was coming on, no supper and no place only among the brush for my bed for the night. My lunch was all gone at dinner time. Mother only having furnished me a little expecting to overtake me shortly. After resting a while I concluded to travel on as long as I could see, in the mean while casting anxious glances back towards the city hoping that Mr. Larsen and the folks would be coming along, but in vain did I look. I walked on till I got very tired when I laid down to rest tying the cow with the rope around one of the large rocks of which there was plenty on the roadside. Being tired I soon went to sleep. I did not dream like Jacob of a ladder reaching to heaven and of angels walking up and down, but sometime during the night $I$ awoke shrivering with cold. I could stand it no longer, having no matches so as 
to make my only chance to warm up was by getting up and travel. This I did. I remember while walking along I saw to the right of my way as though it was a white fog throughout the valley and thought that was what it was. But I learned afterward that it was the great Salt Lake that I was passing. It was the famous bathing resort known as Garfield Beach now is, to which so many thousands of late years has gone for pleasure, but at that time it was a lonely place. I took many short naps during the night, and after each one I had to walk a while to warm up. In the morning I came to some scattered houses along the road, and I went in one place and succeeded in making the woman understand that I wanted something to eat. I had learned to say "hungry" and that with yes and no and a few other words was all the English that I had yet learned, but I now found use for all I knew. I was given a piece of bread with peaches, and it tasted, oh so good. I did the same again at other places and was successful of obtaining such as needed for the body.

I reached Toelle City that afternoon, and expected that. Mr. Larson and the folks would come along that evening but they did not. I found the place where Larson had told me to stop and when night came they gave me an old quilt and told me I could lay in the strawpile. Of course that was not as nice as it might be, but it was far better than the night before. Larson did not come the next day nor the next, but every evening I was looking for the folks, and finally one evening about dusk they came along. Father and Mother was glad when they found that I was all right. I had been sleeping in the straw each night and begged my food from house to house. I felt ashamed of my way of living and did not go to the same house' more than once though. I do not remember of being refused by any.

Toelle City was half the distance from Salt Lake City to Vernon, and the next day we traveled on again. This time I was soon left behind, but I had no trouble in finding the road. I arrived at Larson's sometime the next day, having stopped over night with a Mr. Lewis with whom Larson had made arrangement for my stay as he passed by. The farm 
where we were to live was yet four miles away, but before going there Larson told Father that we better have a more perfect understanding. He was now informed that Larson could not afford to pay him more than fifty cents a day. As for me he could make no certain promise but of course if I proved to be a good boy he would pay me what was right. We found us in a wildemess away from everybody with the exception of four or five houses there being that many families living at Vernon at that time and Father saw no way to do but to agree with Mr. Larson and do the best he could. The farm we was to work, though but a small one, we learned was good land, and it was thought by the use that we might do fairly well. But how we were to live till a crop could be raised was the question of 'great importance that confronted us. Flour at that time was twenty-five dollars per hundred pounds. Bacon one dollar per pound, dressed beef by the quarter twenty-five cents per pound, and everything else in proportion. So even if Father could have earned fifty cents a day it would been impossible for him to provide the necessities of life thereby but Larson had nothing for him to do only for a few days, now and then, and for me he had no use at all. The house in which we were to live was of the style as all the rest in that part of the country, being a little low log cabin with dirt roof. But it was in a delapidated condition, the mud with which it was dubbed had fallen off in many places, leaving large enough holes to put the hand through. There was a kind of a door and one half window, but no floor but the ground, and this was our first home in Zion.

We got some work with a Mr. Nilson who was living in Toelle. City but having a farm in this place helping him to dig his potatoes receiving our pay in potatoes. Besides we got permission to plow his patch afterward, and also potato patches belonging to other parties picking up in this way a good supply of that article. We struck some where the potatoes had been dug in a careless manner leaving good many in the ground, and it was a good thing for us. It was the only supply of provision we had for winter and we had no prospect of anything else. I got a job with a Bishop, Barnes 
who had a farm here where one of his plural wives were living but he his chief home was somewhere on the Jordan River not a great ways from Salt lake City where he was the Bishop of one of the wards. I together with another boy were to herd his sheep. I began Nov. 1st and we were to herd till April 1st five months. Bishop Barnes was to pay me ten dollars per month. I had nothing to wear on my feet for winter so he was to get me a pair of boots at ten dollars, and for the other four months. I was to have a cow. Though this agreement was made I entered upon it blindfolded, that is I knew nothing about what was before me. The sheep at first were brought home each night and while the weather was good, though a lonesome job it was not so bad. I soon came to learn more about the duty of a sheepherder. The sheep was moved out from the settlement about seven miles and a temporary hut prepared for us boys, and a brush coral for the sheep. We had to do our own cooking and to this end we were provided with an iron kettle, a breadpan and a half gallon tin bucket. There was no water nearer than the settlement from whence we had moved, and we had to melt snow to get that useful article and for this purpose the iron kettle came into use. The breadpan was used as a frying pan as we did not have to make bread, getting that ready for use from home. We were furnished with a piece of butcher knife, about half broken off, and without handle. No other utensils that I now remember but an ax with which to chop our wood but we frequently had to use it to cut our bread which was often froze. We as a rule had plenty to eat, of bread and beef, the latter was kept fresh hung in a cedar, and while we could keep from freezing had plenty of potatoes but it got too cold for us to take care of them. Mr. Barnes would generally come and see us once a week and bring provisions. At one time he was later in coming than usual and perhaps our appetite had been keener, at any rate our bread all gave up and for a few days we lived exclusively on beef, and soon that was gone and we had nothing. We got up one morning and had only a small piece of beef which we divided between us, hoping that our boss would be there before night, but he did not come. When night came we concluded to kill a 
sheep thinking our condition would justify the act. My comrade whose name was William declared we must have something to eat, and did not remonstrate. One of the best looking wedders was selected by us, thinking his meat would be the best looking and eatable. William being the oldest was going to knock him in the head with the ax while I' strattled his back holding him by the wool. We thought perhaps after knocking him down we could, by piece of this old knife we had cut his throat, though it was exceedingly dull. William gave the critter a tap with the ax, but not hard enough, and my hold not being firm enough away he went into the herd, numbering about one thousand, and though we tried it was impossible for us to find the same one again. This discouraged us, and we agreed to wait another twenty-four hours fully determined that if $\mathrm{Mr}$. Barnes did not in the meantime turn up with something for us to eat, we would have some by some means. So we retired, our hunger seemingly appeased after our failure in butchering. The next morning we felt about as well as usual, though a bite of breakfast would have been acceptable, but we had now made up our minds to wait if need be till evening. But sometime during the day the boss arrived with a sack of provisions, and we were supplied with something to satisfy the cravings of nature. We told him we had been without food for two days, but said nothing about the effort the night before, nor of our intentions, not that we considered that it would been wrong had our resolution been carried into effect, but we deemed it not needful to tell. Neither did we notice the poor sheep who received the lick at any time, so presume he was not serious hurt. . . .

My parents and sister had fared worse than me as far as living is concerned having had nothing most of the winter to live upon but potatoes and coffee made from wheat. It was seldom that they had bread in the house, and such articles as meat and butter was not thought of. Had we come to larger settlement where work was going on it might have been different, but in this out of way place nothing was done all being poor and in no need of employing any help. I came home on the first of April to share with the folks in what they had but did not remain to home long but went to work 
for a man by the name of Pearson. This was farm work and though it required more exertion, I preferred it to herding sheep. I think father succeeded in borrowing some wheat from Mr. Larson to repay after harvest, so by this means obtained bread while he done his work on the farm. I remember our first Sunday after our arrival at Vernon, we were all going to meeting. While on way we did not know Sunday from any other day as no religious services were held, at least I do not remember, but few occasions when the people were called together for meeting, and that was generally in the evenings, and not of any special day. People coming as we did from what we had been taught was Babylon of course expected something grand in Zion. The settlement being small of course there could not be much of a gathering, but I think nearly all living in the place was there. But it turned out not to be a religious meeting, at least it did not so seem to those not initiated to the custom prevailing in Zion. Questions in regard to stock and fences over which trouble had been brewing in the past was brought and discussed, the particulars of which I do not remember, but it seems like all had a grudge against Larson and he in turn called them all rascals. The meeting was broken up in disorder and I can remember that my parents felt sad over the condition of things and well they might. Having left home and all on earth for to gather with the people of God and to learn more perfect by the way of the Lord to find themselves among a people who by word and action, even upon the Lord's day when they had come together pretending to worship God, showed that they were strangers to the love of God. My parents found comfort in the thought, that perhaps in this out of the way place, the actions of the people should not be considered as a representation of the saints, and the hope was indulged, that if we could get to some place nearer to the center or to the larger settlements we might find a different order of things. So we found ourselves still in Babylon and the resolve was made to leave that portion of the land as soon as circumstances would permit, and seek a location somewhere among the more worthy children of Zion.

Mr. Larson who had been the presiding officer of the 
branch at Vernon was released shortly after our arrival at Vernon by the bishop in Toelle, and Mr. Pearson, (my boss) was appointed to take his place. This man was very zealous in his religion, and I believe he was a man that would be ready to do almost anything that the authorities would council and not stop to ask whether it was right or wrong. He too believed it was his duty to enlarge his kingdom by taking another wife. Though I was but a boy he told me of his intentions, and he was constantly making preparations about his home to provide for a larger family. He too went courting now and then when he could think of a possible chance to find a concubine. Once at Harvest time we had made our arrangements to stack wheat, the horses were hitched to the wagon and I was to drive down to the field and Pearson was going to a neighbors to borrow a fork that we needed, and was to come across lots and meet me in the field. It so happened that there was a young unmarried woman where he was borrowing the fork, one that the man had had his eyes on for some time, and her company must have been pleasant for Pearson stayed (half the day at least) it seemed to me who waited in the scorching sun with no company good or bad but the horses. I presume time passed more rapidly with $\mathrm{Mr}$. Pearson and that he had a good time or he would not remained so long. His wife, the woman whom he had covenanted to love and honor as such, was often complaining because of his courtships and with tears pleaded with him. Of course this was kept from me as much as possible, but as I was constantly around I could not help to observe that there was trouble between them. While I at that time did not fully comprehend all, I have in my reflections in more mature age been able to conceive what $\mathrm{I}$ at that time only in part understood.

I had been with Pearson in Toelle Valley at one time putting up hay, and after we got through on the road home we were stopping in Toelle City. Pearson and I was sleeping out I think by a hay stack. It happened that Brigham Young and his company was coming out there to preach, and Pearson being a good Mormon stayed to take in the meetings, and I stayed also. It suited me. When Brigham and Co. came 
they were seen quite a distance on the plain or at least an emense cloud of smoke bespoke that Young and his following was approaching. Everybody marched out to meet him. I with the rest, while martial music filled the air and cheered the spirit. Brigham's carriage came first drawn by four horses and accompanied with a mounted guard armed with such weapons as was generally had in the territory in those days. I think there was about fifteen or twenty of them. He was followed by other carriages whose horses were not so good as Brigham's and the drivers unmercifully lashed them with the whip to make them keep up. As Brigham's carriage passed the crowd all uncovered their heads and Hurrah! for Brigham as if he was a temporal monarch and not a humble minister for Christ.

After Brigham's reception which was in the evening, I think about sunset or a little before, the band furnished music on the street till late in the evening serenading $B$. Young at his lodging and other of the leading citizens and among them a man by the name of Nelson, whom was manufacturing whiskey on a small scale. It was late when they came to Nelson's residence and I believe he had retired as I do not remember a light being in the house. I had followed with others of the young being fond of music and to see what was going on. I remember Nelson coming out after a while, and it seems that he knew what was wanted for his voice was distinctly heard. "Come down in the cellar, boys" and they obeyed. It was the end of the music that night, and how long these sons of Zion indulged at the cup I did not learn as I sought my resting place at the haystack. To my surprise I learned that Mr. Pearson had not yet retired, nor did he come at all that night. It was learned afterward that he had been courting some lady and so was hindered. Surely if there is any reward for the practise of plural marriage, Mr. Pearson is entitled to one for though I think he never attained to the state of polygamist, he tried his best. It was not his fault.

I did not at that time give religion serious consideration, but my parents were much disappointed with matters in general as they found them. Vernon was an isolated place 
far from leading authorities of the church and hence it was thought from proper influence and every effort was put forth to obtain a team wherewithto move our scanty store to some other settlement. All grains raised was exchanged for yoke of oxen and a wagon, so as soon as the condition of the weather and road would permit in the spring of 1866 we were again on the move. It was my parents intentions when coming to Utah to have gone North of Salt Lake City, and now they concluded to try that part of Zion. I think it was sometime in March that we started out, traveling but very slowly as the oxen were poor, feed scant and we had two or three cows that were not in a condition to travel fast. I remember nothing of the trip but it being slow and tedious. We traveled about 140 miles and came to Bear River about ten miles from Brigham City. Here we found preparations were beginning to be made for a new settlement, by damming the Malad River a tributary of Bear River to raise the water with which to irrigate the land between the two streams. This at that time was a fine country for stock, grass being in abundance, and we were glad to stop and join in the work to be done. Trouble was not yet over, for now as father wanted to put in a crop at least so as to raise enough for bread, he had no seed though he could have the land, neither did he have bread for the family until a harvest could be hoped for. Finally father found a man that loaned him wheat by him agreeing to give him two bushel for one after harvest. Father and I labored nearly all summer on the dam. Our crop would have been a failure had we not more than for that country a usual fall of rain as we did not get in shape so to be able to irrigate until late in June or perhaps in July before water was gotten out. In ordinary seasons everything would have been burned up by that time. But while the rain was good for growing crops it was hard on us who camped there without tent or covered wagon and with only such protection as a wagon bed taken apart could furnish.

Later in the summer father and I went up into the mountains and obtained some poles and small logs which together with some willows that grew on the bank of Bear River was 
the building material for our house for winter. A dugout covered with poles and willows and after that with dirt was the house now completed for the winter. There was one door and half sash with four small light was the only window. But it was the first habitation of our own that we had in Zion and fully as good as any that we had lived in. So considering the conditions of the past we began to think that we were quite comfortable. It was during the winter of 66 and 67 that news of the Reorganized Church or the Josephites first reached our ears. We did not see any of the Elders nor did we meet any of the members of the church, but somehow the news reached us that the "Josephites" had missionaries in Utah and one man by the name of Ageson who was in the habit frequently to from Bear River to Brigham City, would return and somehow becoming posted on the claim of the Josephites called our attention to certain portions of the Bood of Doctrine Covenants which caused some to begin to see that there was some grounds for the claims of the Reorganization. Later we heard of some Josephites holding meetings on Sundays a few miles north of Brigham City, and father and a man by name of Ole Carlsen and I went there to meeting; it was a walk of about ten miles; through snow and slush but that was not considered so much to us in those times. We only attended these meetings two or three times, (I do not remember which) and Carlsen, father, and I were baptized.

The meetings were held in the house of David Powell whom now live near Stewartsville, Mo. I remember especially at one time the spirit's presence in the meeting. Several had spoken and some had been singing, it was sort of a testimony meeting held by a few who had lately come out of the Utah Church and united by the Reorganization. I had understood but little but under the prevailing influence I felt like Peter upon the "Holy Mount." It was good for me to be there, instead of becoming tired as the meeting was long I wished it to continue. But it was not all that felt as well as I did for I remember that Mr. Carlson got up and spoke and told us that he thought the spirit present was not 
of the Lord. This statement was a surprise to me and an opinion on that I though a boy in My seventeenth year I think it was the following Sunday Mr. Carlson, father, and I were baptized and a number besides. I think ten or twelve altogether. David Powell whom was an elder officiated. It was not until several days after the meeting above referred to that I learned that something more than common transpired. But it was then told that the gift of tongues had been enjoyed which I was now prepared to believe by the silent testimony to me that the work was of the Lord. It left an impression upon me that will never be obliterated while my niemory shall last.

\title{
LUMBERMEN AT CLINTON: NINETEENTH CENTURY SAWMILL CENTER
}

\author{
by George Wesley Sieber \\ Wisconsin State University-Oshkosh
}

Professor Sieber ${ }^{*}$ was born in Evansville, Indiana in 1930 but has made Wisconsin his home since 1943. He received his Ph.D. in history from the University of Iowa in 1960 and has. been teaching at Wisconsin State University since 1962. Professor Sieber is presently engaged in writing a book length manuscript: "Sawmilling on the Mississippi: An Iowa Firm in the Nineteenth Century," which will be submitted to Iowa University Press. The following article is based primarily on the W. J. Young Lumber Company papers located at the University of Iowa.

This article depicts the role of Clinton, Iowa in nineteenth century lumber production, the companies, the men who ran them, and their socio-economic role as employers. Attention is focused on the labor force and wages. Emphasis is on W. J. Young \& Company whose records constitute the main source of the study.

"Professor Sieber has been the author of two other articles which have appeared in the ANNALS: "Sawlogs for a Clinton Sawmill," Vol. 37, No. 5, (Summer, 1964) and "Railroads and Lumber Marketing 1858-78: The Relationship Between an Iowa Sawmill Firm and the Chicago \& Northwestern Railroad," Vol. 39, No. 1, (Sumnier, 1967). 
Copyright of Annals of Iowa is the property of State of Iowa, by \& through the State Historical Society of Iowa and its content may not be copied or emailed to multiple sites or posted to a listserv without the copyright holder's express written permission. However, users may print, download, or email articles for individual use. 